\title{
Experiential Learning in Initial Teacher Education: Do Schools have Mentoring Capacity?
}

Kgomotlokoa Linda Thaba

\author{
School of Education, University of Limpopo, South Africa, Private Bag x1106, Sovenga, 0727 \\ Email: lindathaba@yahoo.com, \\ Matshidiso Maria Kanjere
}

Turfloop Graduate School of Leadership; University of Limpopo; South Africa, Private Bag x1106, Sovenga, 0727

Doi:10.5901/mjss.2014.v5n27p537

\begin{abstract}
This paper focuses on experiential learning of student teachers and the perceived capacity of mentoring schools. Experiential learning in initial teacher education requires mentoring schools to provide a learning environment in order to equip student teachers with both subject content knowledge and pedagogical content knowledge. However, the crisis in the South African education system lies in a lack of the development of professional skills of teachers, in addition to insecure classroom competence. The prevailing low quality of education has to dramatically change through a well-equipped initial teacher training programme that produces an adequate number of competent teachers. To understand and curb challenges emanating from practice teaching, large scale research is needed to explore the relationship between experiential learning and mentoring schools. The question raised is how to engender in schools a sense of caring and responsibility towards student teachers. In order to respond to this question, I critically analyse the literature on experiential learning in initial teacher training.
\end{abstract}

Keywords: experiential learning, mentoring school, initial teacher training, subject content knowledge, pedagogical content knowledge

\section{Introduction and Statement of the Problem}

The failure of higher education to offer on delivery of good initial teacher training leads to the high failure in public schools in South Africa. The crisis in the South African basic education system in particular is a cause for concern with regards the development of teacher professional, individual and socialisation skills and classroom competence. Jansen (2011: 103) argues that collapse of the South African school system is not only known locally, but it has been reported internationally in New York Times where lazy teachers, irresponsible unions, lack of accountability and the collapse of discipline were identified as some of the causes. The widespread knowledge of this collapse signifies its severity and made a call loud and clear for immediate intervention. Modisaotsile (2012: 01) argues that the high enrolment of matriculants with poor results and learners who fail in higher education, happens year-in-year out. The basic education system, as the supplier of universities and provider of experiential learning facilities for student teachers, does not perform up to standard. It provides universities with poor material and inadequate experiential learning facilities. The low quality supplies of students, produces low quality teachers, who are expected to take high responsibility to educate the nation.

These teachers become primary implementers of the national curriculum in schools and their failure to execute their responsibilities results in a further collapse in the basic education system. In an attempt to guard against such a perpetuated collapse in the basic education system, the higher education qualifications for teachers need to be benchmarked against contextual variables and realities (DoBE and DHET 2011: 3). This is because teaching is recognised as absolutely vital to the social, cultural and economic health of the nation (Lanier (1997: 1). Therefore teaching curriculum requires continuous reviews to cater for new plans in experiential learning and school mentoring.

The dawn of democratic South Africa in 1994 brought with it a necessary curriculum change. For the teachers to assume new roles, they need disciplined schools with a good learning environment. The school functionality improves school mentoring capacity and improved experiential learning by student teachers during practice teaching. In order for the entire education system to be effective, schools should be functional, starting with efficient classroom practices by well-trained teachers. The effectiveness of teachers ensures total functionality of the education system. This assertion is supported by Shiundu and Omulendo, (1992) who argue that 'the teacher plays an important role in achieving educational objectives, implementing education policies and contributes to the upgrading of the quality of educational services'. 
Russels (in Robinson, 2001: 99) in contrast, argues that "in the educational domain, the experience in teaching often leads to ritual knowledge where the culture of teaching rejects detailed scrutiny of the events of teaching". Notwithstanding this routinisation of pedagogical practice, teachers remain invaluable to the realisation of curricular objectives and practices. This calls for universities to produce quality teachers, who received extensive and relevant experiential learning through well capacitated mentoring schools.

\section{Teachers' Training Programmes}

The design of teachers' education programmes contributes towards either addressing or perpetuating the collapse in education system. To guard against perpetuating the collapse in education system, there is a need to redesign teacher education programmes with a purpose to transform the present and the future teaching personnel. Education programmes should address new perspective of knowledge based economy by focusing on rethinking the teachinglearning process which prepares the teaching personnel to meet the changing social and economic demands, by adopting a complex, evolutionary and responsive approach, Serdenciuc, 2013: 754\&755). This new approach involves preparing teachers to "have a deep conception of the nature of society and of their own role in influencing the shaping of social goals", (Abubu and Donkor, 2014: 34).

"Teacher training is regarded as a backbone of the success of any education system", (Tabot and Mottanya, 2012: 247), whereas, teaching practice is a fundamental process to help bridge theory learnt in the training college and the actual practice of teaching. The student teaching practice and the assessment of experiential learning during this time play a significant role in preparing student teachers for the teaching profession, (Du Plessis, Marais and van Schalkwyk, 2011:23). Initial teacher education policy and research on teacher education provide framework on student teachers' practical learning. Senne-Dibbe, Nkwe and Wessels (2013: 230) argue that research and policy acknowledge the fact that the way teachers are educated contributes towards teacher quality. The relationship between quality education and quality of teaching and learning is very clear in Badenhorst and Badenhorst (2011) study. They argue that "the development of a strong and functional education system is closely linked with quality of teaching and learning taking place at schools", (2011: 1). The schools that strive towards this functionality provide a mentoring capacity needed in experiential learning. For initial teacher education to produce quality teachers, professional, personal and innovation skills, teachers' identity, critical thinking and deliberative dialogue should be promoted in the curriculum and be experienced in the mentoring schools during practice teaching. Samuel and Stephens (2000: 476) argue that 'the specific identity that the student teachers develop is deconstructed, constructed, and reconstructed through the course of the preservice teacher preparation programme'. Moreover, 'in the lecture halls and school-site teaching practice, the questions and activities must encourage independent and critical thinking and must teach student teachers to search deeper and to weigh up ideas in the light of logical argumentation', (Marais 2010: 186).

The universities and the colleges that offer teacher education programmes ought to deliver a curriculum that blends theory and practice through teaching practice. A teacher training programme, a well-planned teaching practice and mentoring schools facilitate fruitful experiential learning and engender good classroom practices. Teaching practice is, essentially, an experiential learning process that provides contextual grounding to the realities and challenges of the classroom. It provides room for student teachers to explore their subject content knowledge and pedagogical content knowledge in the real school setting. It equips teachers with survival skills and a novel orientation to the teething problems beyond the theoretical approaches of the university lecture hall. It is this activity that enhances teachers' innovativeness in teaching and leads to quality education. Simultaneously, highly motivated teachers are groomed and motivate learners towards scholastic achievement. The schools with 'a team of highly motivated teachers' are turned into functional schools which provide a platform for school mentoring during student teachers' experiential learning.

\section{Teaching as a Profession: South African Initial Teacher Education and Teaching Practice}

South Africa, like other countries, requires a continuous supply of teachers to meet the needs and demands of education services for the high population growth in order to meet the United Nations Millennium Development Goals. As a result, in grade 12 learners' recruitment agenda, Department of Education (DoE) argues that "teaching is a noble profession that requires passion, commitment, tolerance, perseverance, character and the dedication to make a difference in the lives of diverse groups of young and older children", (2007: 1). The DoE further argues that "the profession of teaching affords teachers an opportunity to nurture and mould young and growing minds and develops a variety of vital lifelong skills in children". However, the education landscape does not echo the same sentiments as the South African Education Ministry. Most South Africans regard teaching as meant for the under-privileged, because it is under-resourced, teachers 
are under-paid and it is viewed as a profession of low status. The situation is made worse by none or late deliveries of textbooks to schools and improper distribution of section 21 funding which leaves low quintile schools without funds. Despite all these, school teachers are expected to deliver the curriculum policy without fail.

Basic education and higher education institutions fail to implement educational policies and this result in what Jansen and Taylor (2003: 9) refers to as "the policy gap". The policy gap is further supported by HEQF (2009) review when it reveals that "there is a general tendency for teacher education programmes to comply with government regulations in fragmented and mechanical ways, or else by paying mere lip-service to policy requirements". Khan in Jansen and Taylor (2003: 9) outlines the reasons for this gap as the weak capacity within the state, lack of material resources (such as textbooks), the restricting role of national examinations, the weak academic and professional knowledge base of practising teachers and the underdeveloped infrastructure for modern schooling, especially in rural areas. These stated reasons for policy gap, hinders schools to provide required mentoring and relevant experiential learning to practising teachers.

The task of South African government is manifold in an attempting to rectify the situation. A higher education institution, in collaboration with the Department of Higher Education, has the capacity to change "the weak academic and professional knowledge base of practising teachers" (Jansen and Taylor's 2003: 9). Despite the fact that this can be a long- term goal, it will definitely serve as turnaround strategy for the education system in South Africa. The Teacher Development Summit of 2009 has served as an eye-opener and led to development of an Integrated Strategic Planning Framework for teacher education and development in South Africa. It is loud and clear in its 'call for the development and subsequent implementation of a new, strengthened, integrated plan for teacher development in South Africa, which could respond effectively to the current challenges being experienced', ((DoBE and DHET, 2011: 4). The replacement of Norms and Standards for Educators published in 2000 by Minimum Requirements for Teacher Education Qualification (MRTEQ) policy which was gazetted on 15 July 2011 has provided a paradigm shift on competencies and qualifications. In this policy, the experiential learning is currently awarded adequate credits and time and it is regarded as essential feature, unlike with Norms and Standard for Educators.

\section{Policy Framework for Teacher Training in South Africa}

The higher education institutions and their qualifications and teacher education qualifications in particular, required a new theoretical framework to guide policy formulation. "The MRTEQ policy meets the minimum requirements and criteria for higher education qualification as described in Higher Education Qualification Framework Act", (Government Gazette 34467: 2011: 7). The gazette further states that "MRTEQ policy provides a basis for the construction of core curriculum for initial teacher education as well as for Continuing Professional Development (CPD) programmes that are accredited institutions must use in order to develop their programmes leading to teacher education professions". The policy has given preference to the experiential learning and the importance of functional mentoring schools.

Based on the philosophy that "teaching is a complex activity that is premised upon the acquisition, integration and application of different types of knowledge practices and learning", (Government Gazette, 34467: 2011: 10), the new policy provides for these different types of knowledge practices and learning. The MRTEQ policy prescribes that the foundations of education which is composed of philosophy, psychology, history and sociology should be offered in initial education programme. The discussion of five different types of knowledge practices and learning as prescribed by the MRTEQ policy follows:

\subsection{Disciplinary learning/ knowledge}

Disciplinary knowledge refers to subject content knowledge. It is further sub-divided into the study of education and its foundations as well as specific specialised subject matter (specialisation). According to Shulman (1986: 9), subject content knowledge refers to "the amount and organisation of knowledge per se in the mind of the teacher". He further states that "it requires a teacher to go beyond knowledge of facts and concepts to understanding substantive and syntactic structures of the subject matter". Similarly, Goldschmidt and Phelps (2010: 433) assert content knowledge is a requirement to teaching a subject.

\subsection{Pedagogical Learning/Knowledge}

This knowledge includes knowledge of learners, learning, curriculum and general instructional and assessment strategies and specialised pedagogical content knowledge. Knowledge of learners are "issues on the learners which may include 
learner's background scientific knowledge of the concept to be taught, their age, personality factors, problem solving styles and attitude", (Adodo 2013: 594). The latter incorporates aspects of how to disseminate concepts, methods and rules to cater for diverse learners in their different learning spaces.

Shulman (1986: 9) refers to this knowledge area as pedagogical content knowledge PCK. He therefore assets that PCK requires going beyond knowledge of subject matter per se to the dimension of subject matter knowledge for teaching. According to him, PCK refers to most useful forms of representation of ideas, the most powerful analogies, illustrations, examples, explanations, and demonstrations of the ways of representing and formulating the subject that make it comprehensible to others.

\subsection{Fundamental learning/knowledge}

It incorporates communication and information technologies. Its purpose is to equip student teachers with knowledge of academic literacies with the aim to laying foundations for effective learning in higher institutions of learning. These academic literacies include computer literacy, language literacy, technology literacy, science literacy and mathematics literacy.

\subsection{Situational learning/ knowledge}

It involves knowledge of varied learning situations, contexts and environments of education, as well as prevailing policy, political and organisational contexts.

\subsection{Practical learning/ knowledge}

It involves student teachers' knowledge practices and learning based on experiential learning or school-based learning. The model below depicts what MRTEQ policy stipulates on practical learning:

Practical Learning Approach as Prescribed by MRTEQ

\begin{tabular}{|l|l|l|}
\hline \multicolumn{1}{|c|}{ Theory of Practical Learning } & \multicolumn{1}{|c|}{ Practice of Practical Learning } \\
\hline Learning in practice & Learning from practice & Work integrated learning (WIL) \\
\hline Study of a practice based on: & Simulated spaces of practice teaching, micro- & School-site classroom teaching \\
-using discursive resources & teaching. It involves: & involves: \\
-drawing from case studies, -video & -observing & -lesson preparations, \\
records and & -reflection & -observing, \\
-lesson observations & -lesson critique & -reflection of lesson presented by \\
-lesson critique & & oneself or other. \\
\hline
\end{tabular}

In the new approach, practical teaching takes two dimensions, namely, a theory of practice and a real practice. The theory of practice is referred to as learning in practice. As depicted above, it "includes the study of practice, using discursive resources to analyse different practices across a variety of context, drawing from case studies, video records and lesson observations in order to theorise practice and form a basis for learning in practice". Secondly, the real experience of practical learning is captured above as "practice of practical learning". This is further categorised as learning from practice and work integrated learning (WIL). Learning from practice occurs when student teachers are exposed to simulated spaces of practice teaching whereas (WIL) occurs when student teachers are exposed to real teaching practice in the school classroom. Learning in practice involves "teaching in authentic and simulated classroom environments", that which is normally called micro-teaching. Whereas WIL is school-site activity which involves lesson preparations, observing, reflection of lesson presented by oneself or other. It is in the WIL, where student teachers' experiential learning requires functional mentoring school? Based on the state of public schools, do schools have mentoring capacity to provide for experiential learning in initial teacher education?

\section{Do Mentoring Schools have Capacity to Support Experiential Learning?}

Mentoring schools serve as an experimental field where a student teacher is supposed to learn and gain experience on the practice of teaching. Mentoring schools are expected to provide support to student teachers in respect of their personal growth, subject and pedagogy competencies. In the mentoring schools, student teachers work closely with 
experienced teachers or mentor teachers who provide support and guidance. According to Tabot and Mottanya (2012: 247) 'practice teaching aims at the development of student teachers' professional skills, teacher socialisation and teacher professional development".

The enhancement of experiential learning in higher education can be achieved through the creation of learning spaces that promote growth-producing experiences for learners, (Kolk and Kolk, 2005: 205). Many universities have started to create these learning spaces by way of partnering with schools to provide a facility for development of mentor teachers. The purpose of this partnership is to provide schools with required capacity for experiential learning during practice teaching. Tabot and Mottanya, (2012: 247) argue that it equips the student teachers with a field experience to enable them to put theory into practice and familiarize themselves with the conditions under which they will work as trained professionals. According to Badenhorst and Badenhorst (2011: 3) "effective mentoring results with acquisition of skills" where mentors support and give mentees appropriate feedback timeously. In this case classroom teachers or senior teachers serve as mentor teachers. According to Marais (2010: 185) "the mentor teacher is the classroom teacher who guides the student teacher in the school environment".

The acquisition of skills by student teachers as Badenhorst and Badenhorst indicate above depends on ability of the mentoring school to provide school culture and climate which promotes good learning experience. Moreover, student teachers' success is the responsibility of the mentor schools through its capacity to provide school mentors who are able to support and assist student teachers in professional development and school socialisation. On the aspect of teacher socialisation skill and professional teaching, Marais believes that a mentor teacher can carry both of them. Marais (2010: 184) argues that "in social interaction between the student teacher and the mentor teacher - who is an experienced and knowledgeable teacher in the school - the latter not only imparts knowledge and skills but also introduces the student teacher to the context of such knowledge and skills and the accompanying cultural values".

The school mentors ought to assist student teachers to put-theory-in-practice which the college lecturers should have exposed learners to in respect of five different types of knowledge practices and learning, namely: disciplinary learning, pedagogical learning, practical learning, fundamental learning and situational learning, as prescribed by MRTEQ policy. Du Plessis, Marais and van Schalkwyk, (2011: 24) argue that the lecturers involved with training student teachers are continuously striving to improve their teaching approach to teaching practice.

For further support the university lecturers who serve as assessors or supervisors conduct school site visitations. 'The purpose of the personal visit by assessors or supervisors is to assess a lesson which the student presents, to discuss it afterwards and to conduct an interview with the mentor teacher regarding the progress of the student', (Marais 2010: 185). There ought to be formal and deliberative interaction and collaboration between the university or college providing teacher education programmes with the mentor schools. The university lecturers should meet with mentor teachers, in an organised seminar where duties of both are well spelt out. The meeting space should not only be created at school-site where lecturers assess student teachers' classroom performance, however it needs to be created at the universities or colleges facilities. The university or college need to spearhead this process. This will create a platform for information sharing, between those involved in teacher training, and will benefit student teachers in their experiential learning. The provision of student support by mentoring schools exposes student teachers to appropriate experiential learning. According to Qakisa-Makoe (2006: 58) this support ensures 'maximum benefit from the whole learning experience'.

\section{Experiential Learning}

Experiential learning is a philosophy of education based on what Dewey called a theory of experience, (Kolb and Kolb 2005: 193). Practical or experiential learning in teacher education programme has become one of five different types of knowledge practices and learning prescribed by MRTEQ. Experiential learning is a requirement for the initial teacher education. In the report by DoBE and DHET, (2011: 7) experiential learning is referred to as the practice of teaching. They further state that the practice of teaching is a situated and interpretative contextual practice which requires mentor schools to provide learning environments that equip student teachers with grounded subject and pedagogical knowledge. The question raised in this section is whether or not public schools have the capacity to mentor student teachers?

Dewey argues that while tradition had little need for theory since practice was determined by tradition, the new experiential approach to education needed a sound theory of experience to guide its conduct, Kolb and Kolb 2005: 193). Since 'the role of a teacher in child education has fundamentally changed, from old show-and-tell practices', (Lanier 1997: 1), it is vital to expose and engage student teachers with best school and classroom practices to shape their future in the teaching fraternity. "Practical learning is an important condition for the development of tacit knowledge, which is an essential component of learning to teach", (Government Gazette 34467: 2011: 11). The development of teachers' identity, 
critical thinking and deliberative dialogue ought to be developed through the theory and practice of student teachers. Marais (2010: 186) supports what was said above, on critical thinking. He argues that "student teachers 'must cultivate critical thinking in their classrooms and that they must also be trained in appropriate presentation of content when they themselves teach". This is possible if experiential learning and school mentoring are given priority they deserve in initial teacher education.

\section{Conclusion}

The collapse of education in the country has discouraged many individuals to follow teaching career, except students from poor background who are attracted because of Fundza- Lusaka financial scheme. The MRTEQ policy provides framework for initial teacher education and for the first time in the history of teacher education in South Africa, experiential learning and mentoring schools have received special attention. The importance awarded to experiential learning and mentoring schools prompts establishment of university-school partnership, where schools are developed and become favourable learning sites. The main purpose of this partnership is to improve schools mentoring capacity.

\section{References}

Abubu AM, Donkor AK (2014). The In-In-Out Programme of teacher education in Ghana: The Perception of Implementers. IJARER 2 (2): $32-48$.

Adodo SO (2013). Correlate of pre-service teachers and in-service teachers perceived and priorotized students' psychological profiles for the teaching and evaluating basic science and technology (BST). JETEAS 4(2): 305-310.

Badenhorst J, Badenhorst, B (2011). What we have learnt: Student teachers views on the quality of mentoring and teaching practice in township schools. Journal for new Generation Sciences. Vol 9 (2): 1-18.

DoBE, DHET (2011). Integrated strategic planning Framework for Teacher Education and Development in South Africa, 2011- 2025. Pretoria. Government publishers.

DoE (2005). A national framework for teacher education in South Africa. Pretoria: Government Publishers.

DoE (2007). Information guide on initial teacher education. Teaching makes a difference. Become a teacher. Pretoria: Government publishers

DoE (2009). Report of the Task Team for the review of the implementation of the National Curriculum Statement. Pretoria: Government publishers http://www.education.gov.za/LinkClick.aspx?fileticket=kYdmwOUHvps\%3D\&t Retrieved on the 14 October 2013.

Du Plessis EC, Marais P, Van Schalkwyk A (2011). The role of lecturers as mentors in the assessment of student teachers. Progressio 33 (1): 23-42.

Frick L, Carl A, Beets P (2010). Reflection as learning about the self in context: mentoring as catalyst for reflective development in preservice teachers. South African Journal of Education. 30: 421- 437.

Goldschmidt P, Phelps G (2010). Does teacher professional development affect content and pedagogical knowledge: how much and for how long? Economics of Education Review, 29: 432-439.

Government gazette 34467 (2011). RSA government notice on Department of Higher Educationand Training. Pretoria: Government publishers http://www.dhet.gov.za/LinkClick.aspx?fileticket=K7sbUydW4ew\%3D\&tabid=36\&mid=1071

Jansen J (2011). We need to talk. Johannesburg. Bookstorms (Pty) Ltd \& Pan Macmillan South Africa (Pty) Ltd.

Jansen J, Taylor N (2003). Educational change in South Africa 1994- 2003: case studies in large-scale educational reforms. Education Reform and Management Publication Series (1): 1-51.

Kolk AY, Kolk DA (2005). Learning styles and learning spaces: Enhancing experiential learning in higher education. Academy of Management learning and education. Vol 4(2): 193-212.

Lanier JT (1997). Redefining the Role of the Teacher: It's a Multifaceted Profession. A closer look at what being an educator really means. http://www.edutopia.org/redefining-role-teacher

Marais P (2010). Student teachers' experience of practice teaching through ODL. Progressio, Vol 32, ( 2): 181-198.

Modisaotsile B M (2012). The Failing Standard of Basic Education in South Africa. Africa Institute of South Africa (AISA). POLICY brief Number 72 - March2012. http://www.ai.org.za/wp-content/uploads/downloads/2012/03/No.-72.The-Failing-Standard-of-Basic Education-in-South-Africa1.pdf (Accessed on 08 January 2014).

Qakisa-Makoe M (2006). Reaching out. Supporting Black learners in distance education. Progressio: South African Journal for Open and Distance Learning Practice 27 (1 \&2): 44-61.

Robinson M (2001). Teachers as mentors: a critical view of teacher development in South African schools. Perspectives in Education. Vol 19 (2): $99-108$.

Samuel M, Stephens D (2000). Critical dialogues with self: developing teacher identities and roles- a case study of South African student teachers. International Journal of Ecational Research, 33: 475- 491.

Serdenciuc NA (2013). Competency-based education-implications on teachers' training. Procedia- Social and Behavioral Sciences, 76 : 754-758.

Senne-Dibbe C, Nkwe E, Wessels E (2013). Student teacher placement: short- changing teacher quality. Proceedings of the $40^{\text {th }}$ annual 
international conference of the Southern African Society for Education, 26- 28 September Mafikeng, South Africa.

Shiundu JS, Omulando SJ (1992). Curriculum: theory and practice in Kenya. Nairobi. Oxford University Press.

Shulman LS (1986). Those who understand: knowledge growth in teaching. Educational Researcher, 15(2): 4-14.

Tabot BA, Mottanya, CN (2012). Effect of contextual characteristics of teaching practice schools on student teachers' performance in Kenya. Journal of Emerging Trends in Educational Research and policy studies. 3(3): 247- 256. 